\title{
The composition, spatial patterns, and influencing factors of atmospheric wet nitrogen deposition in Chinese terrestrial ecosystems
}

\author{
Jianxing Zhu ${ }^{\mathrm{a}, \mathrm{b}}$, Nianpeng He ${ }^{\mathrm{a}, *}$, Qiufeng Wang ${ }^{\mathrm{a}, *}$, Guofu Yuan ${ }^{\mathrm{a}}$, Ding Wen ${ }^{\mathrm{a}, \mathrm{b}}$, Guirui Yu ${ }^{\mathrm{a}}$, Yanlong Jia ${ }^{\mathrm{a}, \mathrm{b}}$ \\ a Key Laboratory of Ecosystem Network Observation and Modeling, Institute of Geographic Sciences and Natural Resources Research, Chinese Academy of Sciences, Beijing 100101, China \\ ${ }^{\mathrm{b}}$ University of Chinese Academy of Sciences, Beijing 100049, China
}

\section{H I G H L I G H T S}

- Atmospheric N deposition impacts terrestrial ecosystems.

- Composition of wet $\mathrm{N}$ deposition in China scale was first reported.

- Atmospheric $\mathrm{N}$ deposition was underestimated without particulate $\mathrm{N}$ in rainfall.

- Precipitation, $\mathrm{N}$ fertilizer use, and energy consumption influence wet $\mathrm{N}$ deposition.

\section{A R T I C L E I N F O}

\section{Article history:}

Received 22 August 2014

Received in revised form 26 November 2014

Accepted 14 December 2014

Available online 22 January 2015

Editor: P. Kassomenos

\section{Keywords:}

Nitrogen

Wet deposition

Spatial pattern

Composition

Influencing factors

\begin{abstract}
A B S T R A C T
Atmospheric nitrogen ( $\mathrm{N}$ ) deposition is an important component of the global $\mathrm{N}$ cycle, and is a key source of biologically available $\mathrm{N}$. Understanding the spatio-temporal patterns and influencing factors of $\mathrm{N}$ deposition is essential to evaluate its ecological effects on terrestrial ecosystems, and to provide a scientific basis for global change research. In this study, we monitored the monthly atmospheric $\mathrm{N}$ deposition in rainfall at 41 stations from the Chinese Ecosystem Research Network through measuring total N (TN), total dissolved N (TDN), ammonium $\left(\mathrm{NH}_{4}^{+}-\mathrm{N}\right)$, and nitrate $\left(\mathrm{NO}_{3}^{-}-\mathrm{N}\right)$. The results showed that the atmospheric wet deposition of TDN, $\mathrm{NH}_{4}^{+}-\mathrm{N}$, and $\mathrm{NO}_{3}^{-}-\mathrm{N}$ were $13.69,7.25$, and $5.93 \mathrm{~kg} \mathrm{~N} \mathrm{ha}^{-1} \mathrm{yr}^{-1}$, respectively. The deposition of TN and total particulate $\mathrm{N}$

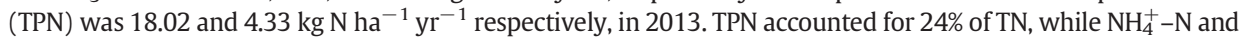
$\mathrm{NO}_{3}^{-}-\mathrm{N}$ made up $40 \%$ and $33 \%$, respectively, confirming the assumption that atmospheric wet $\mathrm{N}$ deposition would be underestimated without particulate $\mathrm{N}$ in rainfall. The $\mathrm{N}$ deposition was higher in Central and Southern China, and lower in North-west, North-east, Inner Mongolia, and Qinghai-Tibet regions. Precipitation, N fertilizer use, and energy consumption were significantly correlated with wet $\mathrm{N}$ deposition (all $p<0.01$ ). Models that included precipitation and $\mathrm{N}$ fertilizer can explain $80-91 \%$ of the variability in wet $\mathrm{N}$ deposition. Our findings reveal, for the first time, the composition of the wet $\mathrm{N}$ deposition in China at different scales and highlight the importance of TPN.
\end{abstract}

(c) 2014 Elsevier B.V. All rights reserved.

\section{Introduction}

The deposition of atmospheric nitrogen $(\mathrm{N})$ is integral to the global N cycle (Galloway et al., 2004; Liu et al., 2011). Anthropogenic activities over recent decades, such as the burning of fossil fuels and fertilizer application, resulted in a rapid increase in the emission of reactive $\mathrm{N}$ (Neff et al., 2002). It was estimated that the production of reactive $\mathrm{N}$ increased from $15 \mathrm{Tg} \mathrm{N}$ in 1860 to $156 \mathrm{Tg} \mathrm{N}$ in 1995, with a further increase up to $187 \mathrm{Tg} N$ in 2005 (Galloway et al., 2008). On the one hand, atmospheric $\mathrm{N}$ deposition has a positive effect on maintaining plant productivity of

\footnotetext{
* Corresponding authors at: Institute of Geographic Sciences and Natural Resources Research, Chinese Academy of Sciences, 11A, Datun Road, Chaoyang District, Beijing 100101, China.

E-mail addresses: henp@igsnrr.ac.cn (N. He), qfwang@igsnrr.ac.cn (Q. Wang).
}

terrestrial ecosystems through enhancing the $\mathrm{N}$ availability (Fleischer et al., 2013; Reay et al., 2008; Thomas et al., 2010; Ti et al., 2012); on the other hand, excessive $\mathrm{N}$ deposition has negative impacts on ecosystem health and services, such as N saturation (Aber et al., 1989; Kopacek et al., 2013), soil acidification (Bowman et al., 2008; Maljanen et al., 2013; Vitousek et al., 1997), and loss of biodiversity (Bobbink et al., 2010; Stevens et al., 2004).

Observations of atmospheric $\mathrm{N}$ deposition are essential for evaluating its ecological effects on terrestrial ecosystems (Galloway et al., 2008; Liu et al., 2011, 2013). Some studies have reported the observed results of atmospheric $\mathrm{N}$ deposition at a local scale (Chen and Mulder, 2007; Huang et al., 2013), from catchments (Chen et al., 2011; Yu et al., 2011), or from belt transects (Sheng et al., 2013; Zhan et al., 2014 ) in China. Data collection, meta-analysis, and models have been used to estimate regional N deposition in China (Lü and Tian, 2007; Jia 
et al., 2014). However, there is currently no representative national scale observation network for atmospheric $\mathrm{N}$ deposition in China. Therefore, it is difficult to compare or evaluate these findings because of the higher uncertainty caused by different sampling and analytical methods. Furthermore, no study has evaluated particulate $\mathrm{N}$ in wet deposition in China, although the fluxes of dissolved wet $\mathrm{N}$ deposition $\left(\mathrm{NH}_{4}^{+}-\mathrm{N}\right.$ and $\left.\mathrm{NO}_{3}^{-}-\mathrm{N}\right)$ have been reported (Zhang et al., 2006; Huang et al., 2013; Shen et al., 2013). As a potential N source, ignoring particulate $\mathrm{N}$ deposition in rainfall would underestimate the $\mathrm{N}$ input through rainfall in terrestrial ecosystems.

In this study, we selected 41 stations from the Chinese Ecosystem Research Network (CERN) to monitor atmospheric wet $\mathrm{N}$ deposition through rainfall events. These stations cover the main types of terrestrial ecosystems in China (Fu et al., 2010). Precipitation was collected monthly, and total $\mathrm{N}$ (TN), total dissolved $\mathrm{N}$ (TDN), ammonium $\left(\mathrm{NH}_{4}^{+}-\mathrm{N}\right)$ and nitrate $\left(\mathrm{NO}_{3}^{-}-\mathrm{N}\right)$ were measured to investigate the composition, spatial patterns, and drivers of wet $\mathrm{N}$ deposition. The main objectives were to: 1 ) investigate wet $\mathrm{N}$ deposition in Chinese terrestrial ecosystems; 2) clarify the composition of wet N deposition; and 3) explore the main influencing factors of wet $\mathrm{N}$ deposition in China.

\section{Methods}

\subsection{Site description}

The 41 study sites cover the major terrestrial ecosystems in China (Table S1, Fig. 1), including forest, grassland, desert, lake, karst, and urban ecosystems (Fu et al., 2010). Based on these stations, we constructed a new observation network to monitor atmospheric wet $\mathrm{N}$ deposition at national scale. These stations are distributed within 22 Chinese provinces and can be divided into eight ecological regions based on climate and vegetation (Fig. 1). The observational network provides a new approach to explore the patterns of atmospheric $\mathrm{N}$ deposition in China from single sites, to ecological regions, and up to national scale.

\subsection{Sampling and analysis}

Precipitation was collected into plastic buckets installed at the height of $1.5 \mathrm{~m}$ above the ground at the onset of rain (or snow) in 2013. The samples were collected over the duration of rainfall, and included soluble and insoluble particulates in precipitation. Collection was conducted about 3-5 times in each month; the samples were mixed evenly to get a monthly sample, and were then stored in polyethylene plastic bottles under $-20{ }^{\circ} \mathrm{C}$.

Each sample was divided in two parts in the laboratory. One part was digested using the alkaline potassium persulfate digestion method, to measure total $\mathrm{N}$ (TN) of mixed rainfall in the continuous flow analyzer (FUTURA, Alliance Instruments, France). The other part was first filtered by gravity through a $0.45 \mu \mathrm{m}$ membrane filter to remove insoluble particulates, and then the concentrations of TDN, $\mathrm{NH}_{4}^{+}-\mathrm{N}$, and $\mathrm{NO}_{3}^{-}-\mathrm{N}$ were measured using the same continuous flow analyzer. The methods of duplicates, blank, and standard materials were used to control data quality.

\subsection{Data calculation and analysis}

The different components of wet $\mathrm{N}$ deposition were calculated using the following equations:

$$
\begin{aligned}
& \mathrm{DIN}=\mathrm{NH}_{4}^{+}-\mathrm{N}+\mathrm{NO}_{3}^{-}-\mathrm{N} \\
& \mathrm{DON}=\mathrm{TDN}-\mathrm{DIN} \\
& \mathrm{TPN}=\mathrm{TN}-\mathrm{TDN}
\end{aligned}
$$

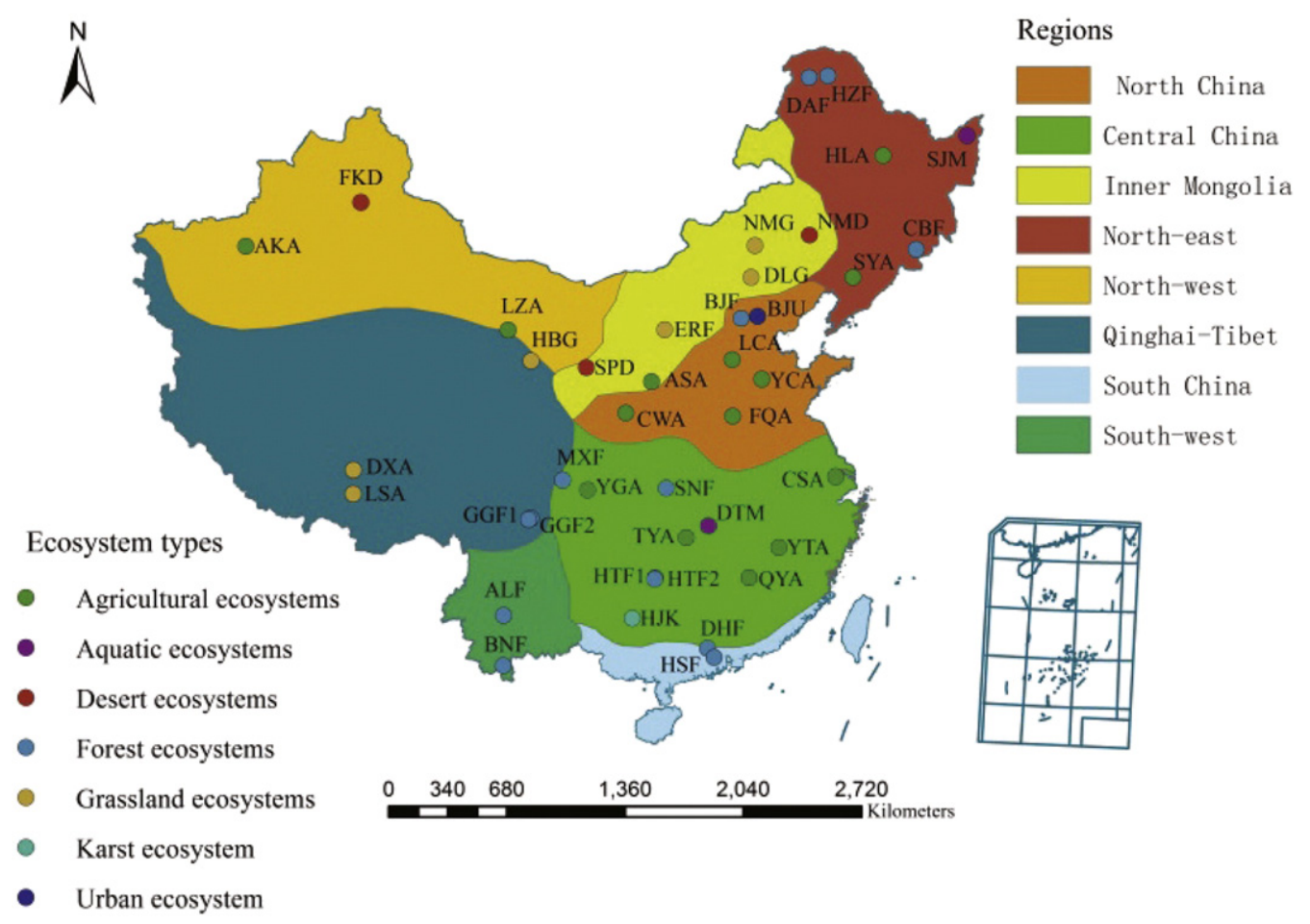

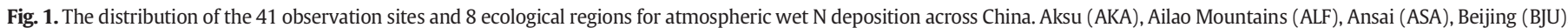

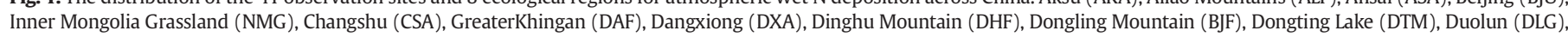

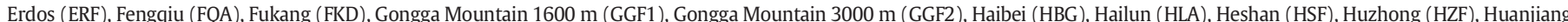

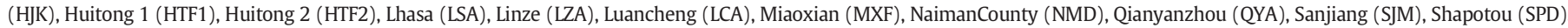

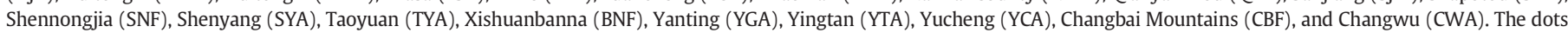
with different colors represent different ecosystem types. 
where DIN is dissolved inorganic N; DON is dissolved organic N; and TPN is the total particulate N.

We calculated the monthly wet $\mathrm{N}$ deposition flux using:

$D_{N}=\sum_{t=1}^{n} \frac{C_{t} \times P_{t}}{100}$

where $D_{N}$ is the $\mathrm{N}$ deposition flux per year, which is the sum of monthly $\mathrm{N}$ deposition flux ( $\mathrm{kg} \mathrm{N} \mathrm{ha}^{-1} \mathrm{yr}^{-1}$ ); $C_{i}$ is the $\mathrm{N}$ concentration of the different components in each month ( $\mathrm{mg} \mathrm{N} \mathrm{L}^{-1}$ ); $P_{i}$ is the monthly precipitation ( $\mathrm{mm})$; and 100 is the conversion factor.

The Kriging interpolation technique was applied to calculate wet $\mathrm{N}$ deposition at a national scale. Taiwan province was not evaluated owing to the lack of monitoring data. Prior to the interpolation, a geostatistical method tool from ArcGIS 10.0 software conducted data analyses, including data distribution, outlier identification, and trend analyses. The optimal variogram model and parameters were then determined. The normal distribution plots and tests are shown in Fig. S1 and Table S2, respectively. In addition, a cross-validation was implemented to evaluate the results of the Kriging interpolation. The crossvalidation analysis and prediction errors are shown in Fig. S2 and Table S3, respectively. The annual deposition flux for China's eight ecological regions, as well as for the whole China, was then obtained using the Kriging interpolation method. The predicted values had high rootmean-square and relatively low $R^{2}$ values, which ranged from 4.61 to 13.15 and 0.24 to $0.46(p<0.01)$, respectively (Fig. S2 and Table S3), because of the limited number of observation sites.
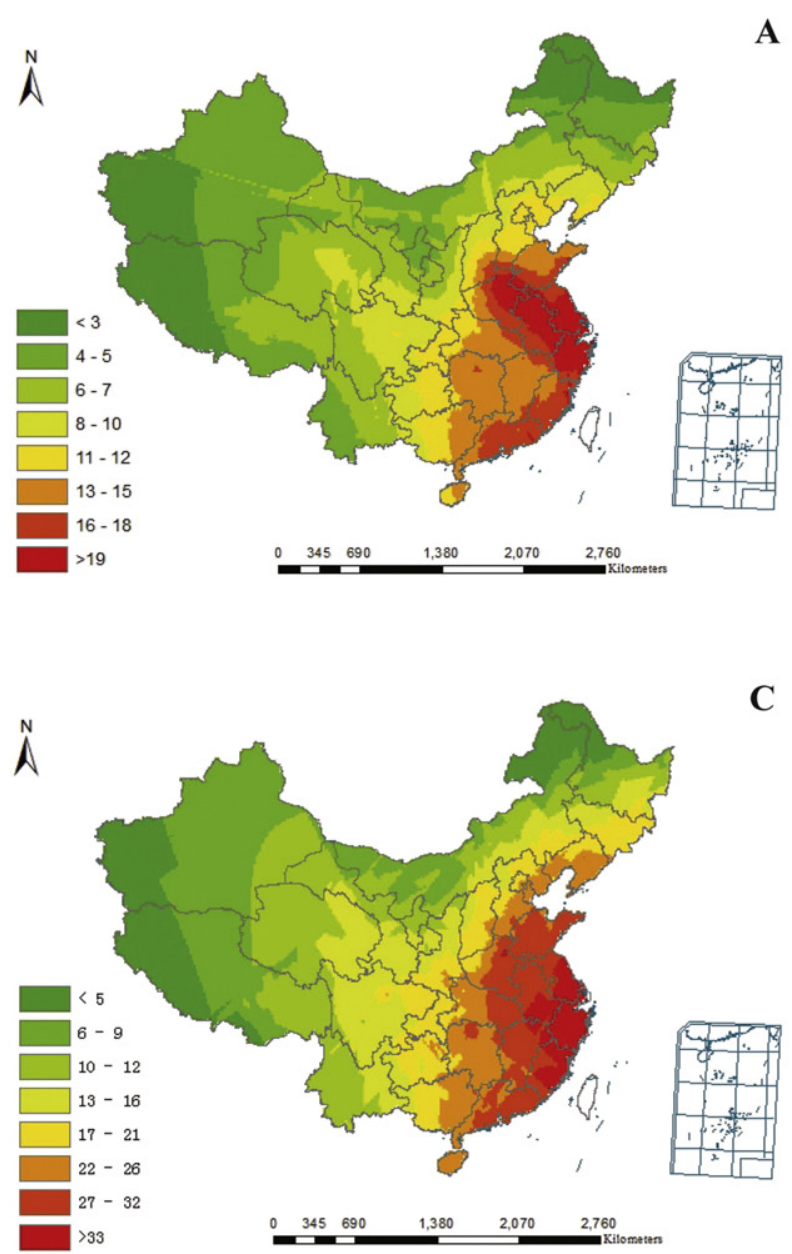

A
Data on the use of $\mathrm{N}$ fertilizer in the provinces (Table S4) were obtained from the China Statistical Yearbook (2001-2010) (Yearbook, 2001-2010b). The data on the energy consumption in the provinces were obtained from the China Energy Statistical Yearbook (2001-2010) (Yearbook, 2001-2010a), which consists primarily of the consumption of coal, crude oil, natural gas and their by-products. Atmospheric wet $\mathrm{N}$ deposition fluxes in provinces were taken as the average of the observation sites. Linear and curvilinear regression was used to evaluate the relationship between $\mathrm{N}$ deposition and the distance between observation sites and nearest provincial capital, precipitation, $\mathrm{N}$ fertilizer use, and energy consumption.

Multiple linear regressions were used to evaluate the combined effects of precipitation, $\mathrm{N}$ fertilizer use, and energy consumption on wet $\mathrm{N}$ deposition. Path-analysis was conducted to evaluate the dependence of the spatial variations of wet $\mathrm{N}$ deposition on influencing factors. A significance level of $p<0.05$ was used for all tests. All analyses were conducted using the SPSS 12.0 program.

\section{Results}

\subsection{Atmospheric wet $N$ deposition}

\subsubsection{Spatial patterns of atmospheric wet $N$ deposition}

The magnitude and spatial patterns of wet $\mathrm{N}$ deposition are shown in Fig. 2. In 2013, the wet deposition flux of TDN, $\mathrm{NH}_{4}^{+}-\mathrm{N}$, and $\mathrm{NO}_{3}^{-}-\mathrm{N}$ was $13.69,7.25$, and $5.93 \mathrm{~kg} \mathrm{~N} \mathrm{ha}^{-1} \mathrm{yr}^{-1}$, respectively (Table 1); In other words, the TDN, $\mathrm{NH}_{4}^{+}-\mathrm{N}$, and $\mathrm{NO}_{3}^{-}-\mathrm{N}$ inputs in China were approximately $12.52,6.63$, and $5.42 \mathrm{Tg} \mathrm{N} \mathrm{yr}^{-1}$, respectively. The TN
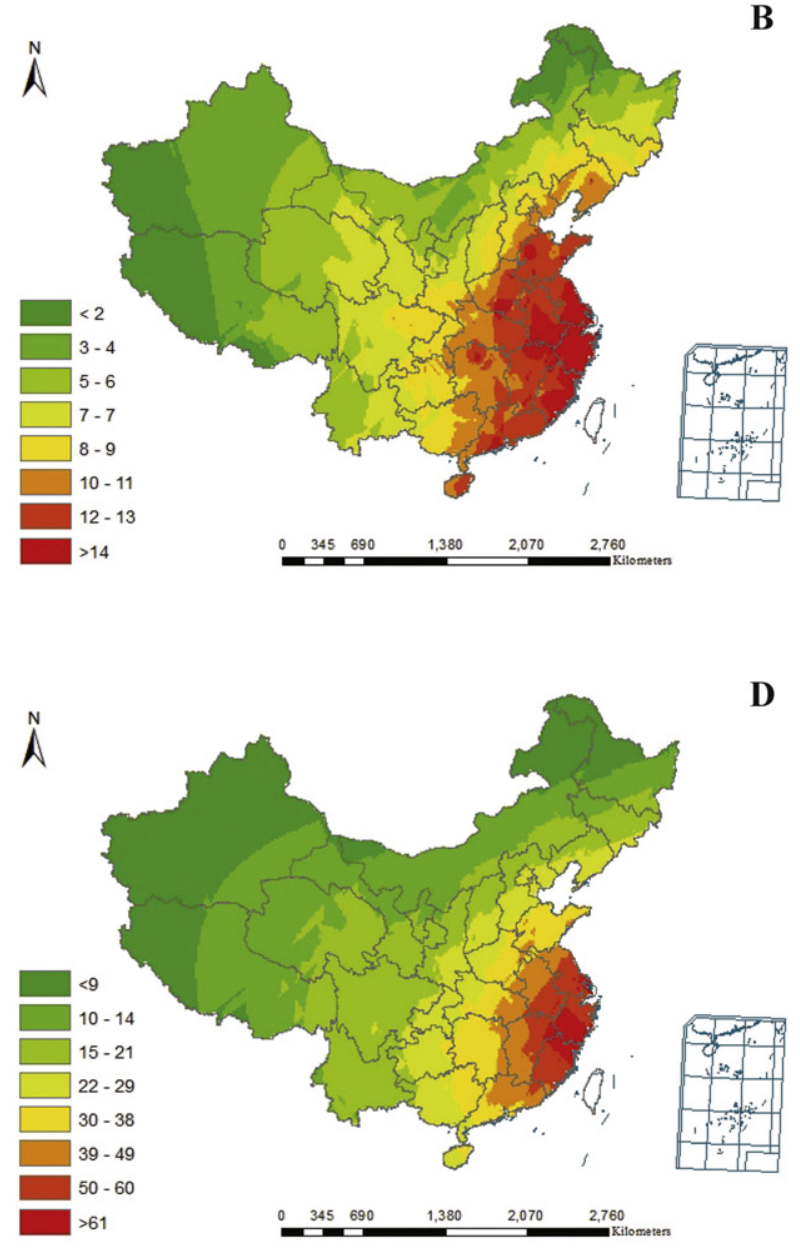

Fig. 2. Spatial patterns of atmospheric $\mathrm{N}$ deposition in China $\left(\mathrm{kg} \mathrm{N}^{-1} \mathrm{yr}^{-1}\right)$. $\mathrm{A}, \mathrm{NH}_{4}^{+}-\mathrm{N}$ deposition; $\mathrm{B}, \mathrm{NO}_{3}^{-}-\mathrm{N}$ deposition; $\mathrm{C}$, total dissolved $\mathrm{N}$ deposition; $\mathrm{D}$, total $\mathrm{N}$ deposition. 
Table 1

Atmospheric $\mathrm{N}$ deposition through rainfall on the basis of different methods and temporal scales.

\begin{tabular}{|c|c|c|c|c|c|c|c|c|}
\hline \multirow[t]{2}{*}{ Reference } & \multirow[t]{2}{*}{ Estimation technique } & \multirow[t]{2}{*}{ Year } & \multicolumn{5}{|c|}{ Nitrogen components $\left(\mathrm{kg} \mathrm{N} \mathrm{ha}^{-1} \mathrm{yr}^{-1}\right)$} & \multirow[b]{2}{*}{$\mathrm{TN}$} \\
\hline & & & $\mathrm{NH}_{4}^{+}-\mathrm{N}$ & $\mathrm{NO}_{3}^{-}-\mathrm{N}$ & DIN & DON & TDN & \\
\hline Lü and Tian (2007) & Data collection $^{\mathrm{a}}$ & $1985-2005$ & 7.13 & 2.75 & 9.88 & - & - & - \\
\hline \multirow{2}{*}{ Liu et al. (2013) } & Summarized previous results & $1980 \mathrm{~s}$ & - & - & 13.2 & - & - & - \\
\hline & & $2000 s$ & - & - & 21.1 & - & - & - \\
\hline \multirow{2}{*}{ Jia et al. (2014) } & Data collection & 1990s & - & - & 11.11 & - & - & - \\
\hline & & $2000 s$ & - & - & 13.87 & - & - & - \\
\hline Zhang et al. (2012a,b) & Measurement ${ }^{\mathrm{b}}$ & 2005-2009 & - & - & - & 6.84 & 24.43 & - \\
\hline This study & Measurement & 2013 & 7.25 & 5.93 & 13.18 & 0.52 & 13.69 & 18.02 \\
\hline
\end{tabular}

a "Data collection" indicates data from published sources.

b "Measurement" indicates data obtained by analyzing the rainfall samples.

deposition was $18.02 \mathrm{~kg} \mathrm{~N} \mathrm{ha}^{-1} \mathrm{yr}^{-1}$ and the annual input of TN was approximately $16.48 \mathrm{Tg} \mathrm{N} \mathrm{yr}^{-1}$. The wet $\mathrm{N}$ deposition showed the following clear spatial distributions. The TN deposition for Central China (CC) and South China (SC) was greater than $35 \mathrm{~kg} \mathrm{~N} \mathrm{ha}^{-1} \mathrm{yr}^{-1}$. The $\mathrm{N}$ deposition in North-west (NW), North-east (NW), Inner Mongolia (IM), and Qinghai-Tibet (QT) regions ranged from 7.55 to $12.84 \mathrm{~kg} \mathrm{~N} \mathrm{ha}^{-1} \mathrm{yr}^{-1}$.

\subsubsection{Components of atmospheric wet $N$ deposition}

$\mathrm{NH}_{4}^{+}-\mathrm{N}, \mathrm{NO}_{3}^{-}-\mathrm{N}$, and TPN were the main components of wet $\mathrm{N}$ deposition, accounting for $40 \%, 33 \%$, and $24 \%$ of TN, respectively (Fig. 3). The ratio of $\mathrm{NH}_{4}^{+} / \mathrm{NO}_{3}^{-}$was 1.22 on average, ranging from 0.82 to 1.35 in the eight ecological regions (Fig. 3). The deposition of TPN was about $4.33 \mathrm{~kg} \mathrm{~N} \mathrm{ha}^{-1} \mathrm{yr}^{-1}$. The deposition of DON was approximately $0.52 \mathrm{~kg} \mathrm{~N} \mathrm{ha}^{-1} \mathrm{yr}^{-1}$, which is small compared with the total $\mathrm{N}(3 \%)$.

3.2. Relationship between atmospheric wet $N$ deposition and proximity of metropolitan areas

$\mathrm{NH}_{4}^{+}-\mathrm{N}, \mathrm{NO}_{3}^{-}-\mathrm{N}, \mathrm{TDN}$, and TN were closely related with the distance between the observation site and the nearest provincial capital (Fig. 4).
When the distance was less than $250 \mathrm{~km}$, wet N deposition increased exponentially with decreasing distance.

\subsection{Factors influencing atmospheric wet $N$ deposition}

The deposition of $\mathrm{NH}_{4}^{+}-\mathrm{N}\left(\mathrm{R}^{2}=0.1975, p=0.004\right), \mathrm{NO}_{3}^{-}-\mathrm{N}\left(\mathrm{R}^{2}=\right.$ 0.3093, $p<0.0001)$, TDN $\left(\mathrm{R}^{2}=0.2522, p=0.001\right)$, and TN $\left(\mathrm{R}^{2}=\right.$ $0.3981, p<0.0001$ ) was closely related to precipitation (Fig. 5). The accumulation of wet $\mathrm{N}$ deposition increased with increasing precipitation. The use of $\mathrm{N}$ fertilizer and energy consumption was significantly correlated with wet $\mathrm{N}$ deposition across the 22 provinces (Figs. 6 and 7). $\mathrm{N}$ fertilizer use was strongly linearly related to $\mathrm{NH}_{4}^{+}-\mathrm{N}\left(\mathrm{R}^{2}=0.5385, p<\right.$ $0.0001), \mathrm{NO}_{3}^{-}-\mathrm{N}\left(\mathrm{R}^{2}=0.431, p=0.001\right), \mathrm{TDN}\left(\mathrm{R}^{2}=0.6678, p<\right.$ $0.0001)$, and TN $\left(R^{2}=0.6708, p<0.0001\right)$. Energy consumption could explain $24 \%, 44 \%, 42 \%$, and $35 \%$ of the total variance in wet deposition of $\mathrm{NH}_{4}^{+}-\mathrm{N}, \mathrm{NO}_{3}^{-}-\mathrm{N}, \mathrm{TDN}$, and $\mathrm{TN}$, respectively.

Models including $\mathrm{N}$ fertilizer and precipitation could explain 80-91\% of the spatial variation of wet $\mathrm{N}$ deposition (Table 2). The final equations did not include the parameter of energy consumption (Table 2), because regressions including energy consumption did not make further variations explicable. Path-analysis showed $\mathrm{N}$ fertilizer use was the main

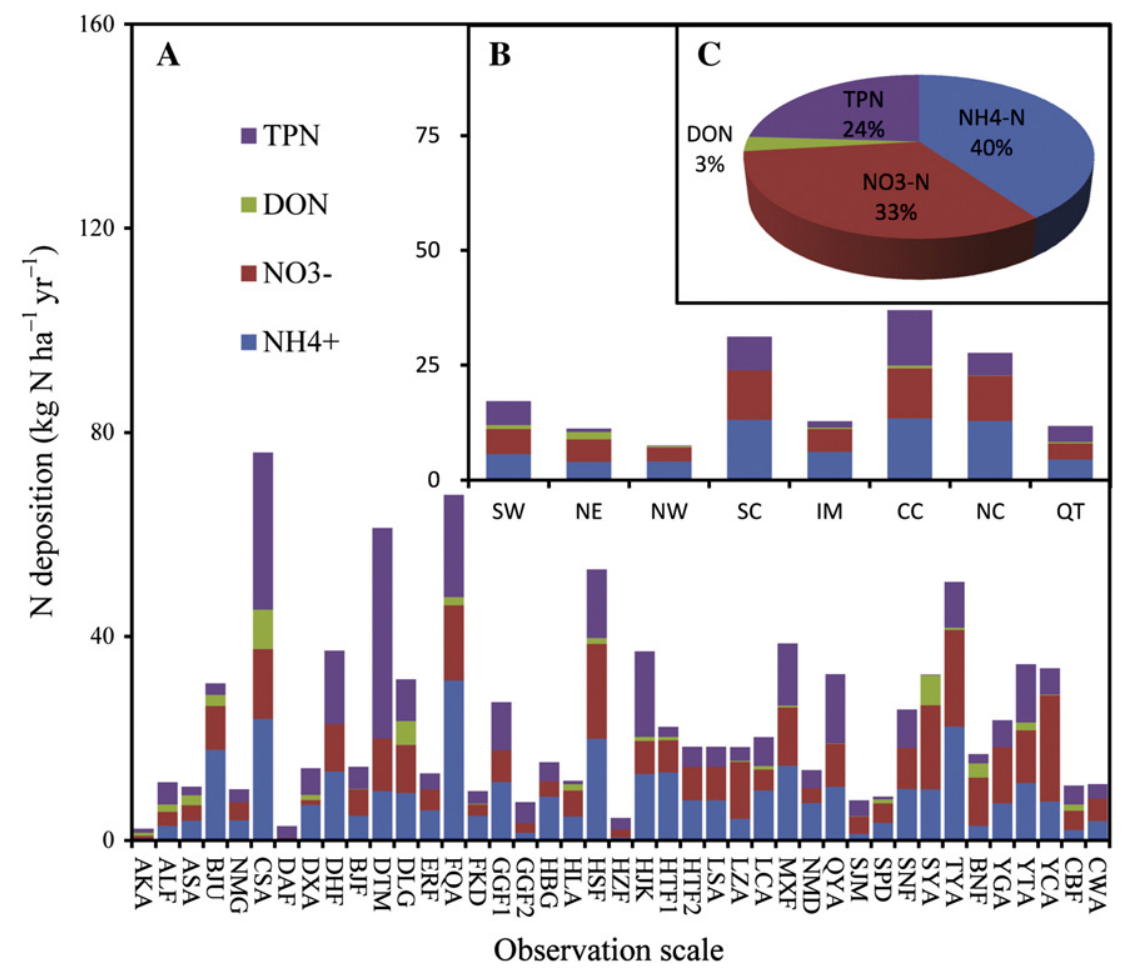

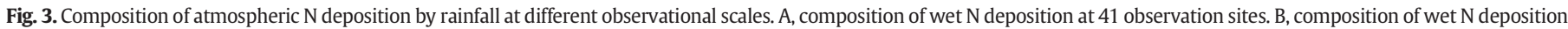

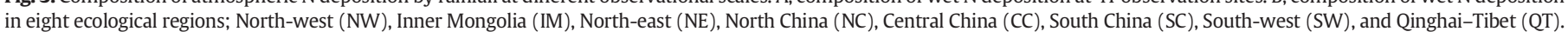
$\mathrm{C}$, composition of wet $\mathrm{N}$ deposition in China. 


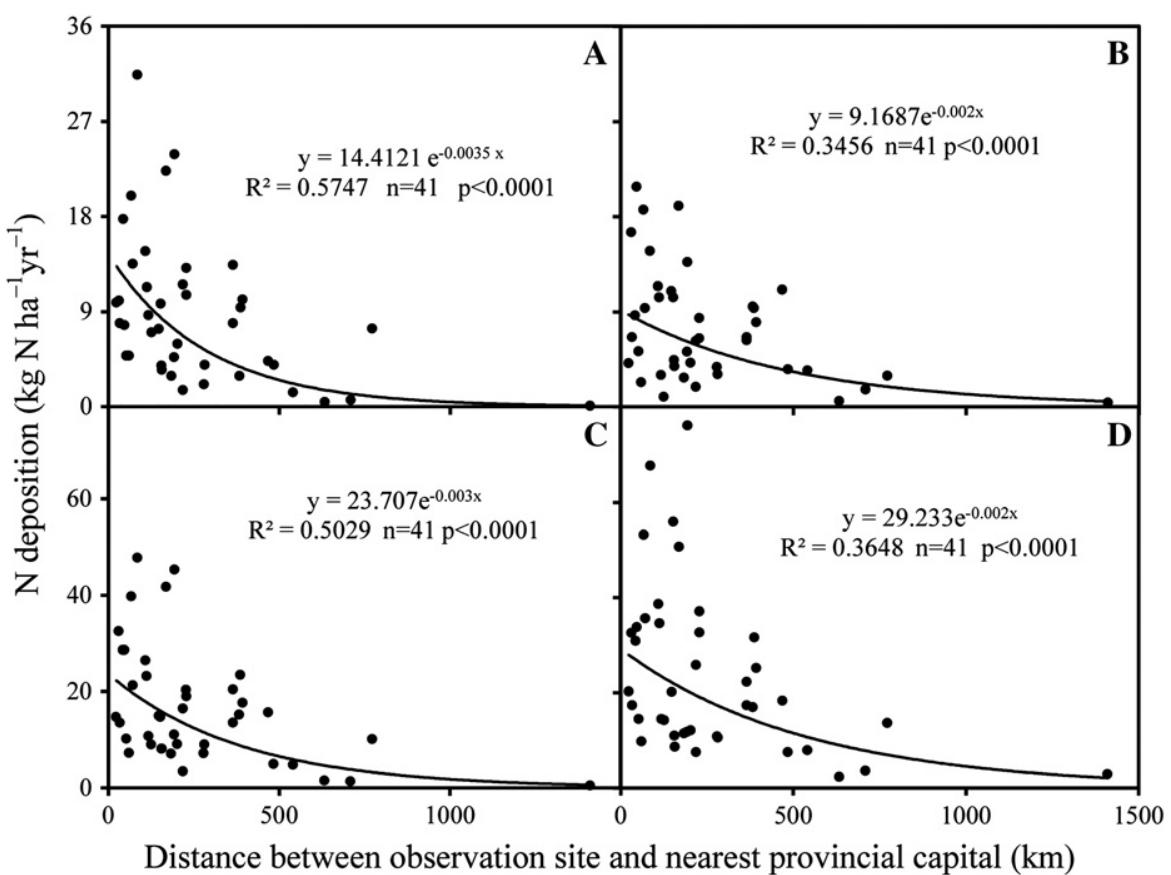

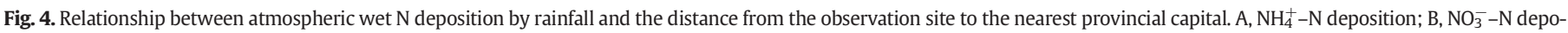
sition; C, total dissolved $\mathrm{N}$ deposition; D, total N deposition.

influencing factor in the analysis of the spatial patterns of wet $\mathrm{N}$ deposition (Fig. 8).

\section{Discussion and conclusions}

Atmospheric DIN deposition $\left(\mathrm{NH}_{4}^{+}-\mathrm{N}\right.$ and $\left.\mathrm{NO}_{3}^{-}-\mathrm{N}\right)$ was approximately $13.18 \mathrm{~kg} \mathrm{~N} \mathrm{ha}^{-1} \mathrm{yr}^{-1}$ in 2013 in Chinese terrestrial ecosystems.
This result was consistent with our previous study (Jia et al., 2014), which reported that atmospheric wet $\mathrm{N}$ deposition in China was about $13.87 \mathrm{~kg} \mathrm{~N} \mathrm{ha}^{-1} \mathrm{yr}^{-1}$ in the 2000s by collecting published monitoring data and employing the Kriging technique (Table 1). Using the same methods, Lü and Tian (2007) estimated that atmospheric wet N deposition was about $9.88 \mathrm{~kg} \mathrm{~N} \mathrm{ha}^{-1} \mathrm{yr}^{-1}$ during $1980-2005$. Taking the average of data from published sources and measurements, Liu et al. (2013)

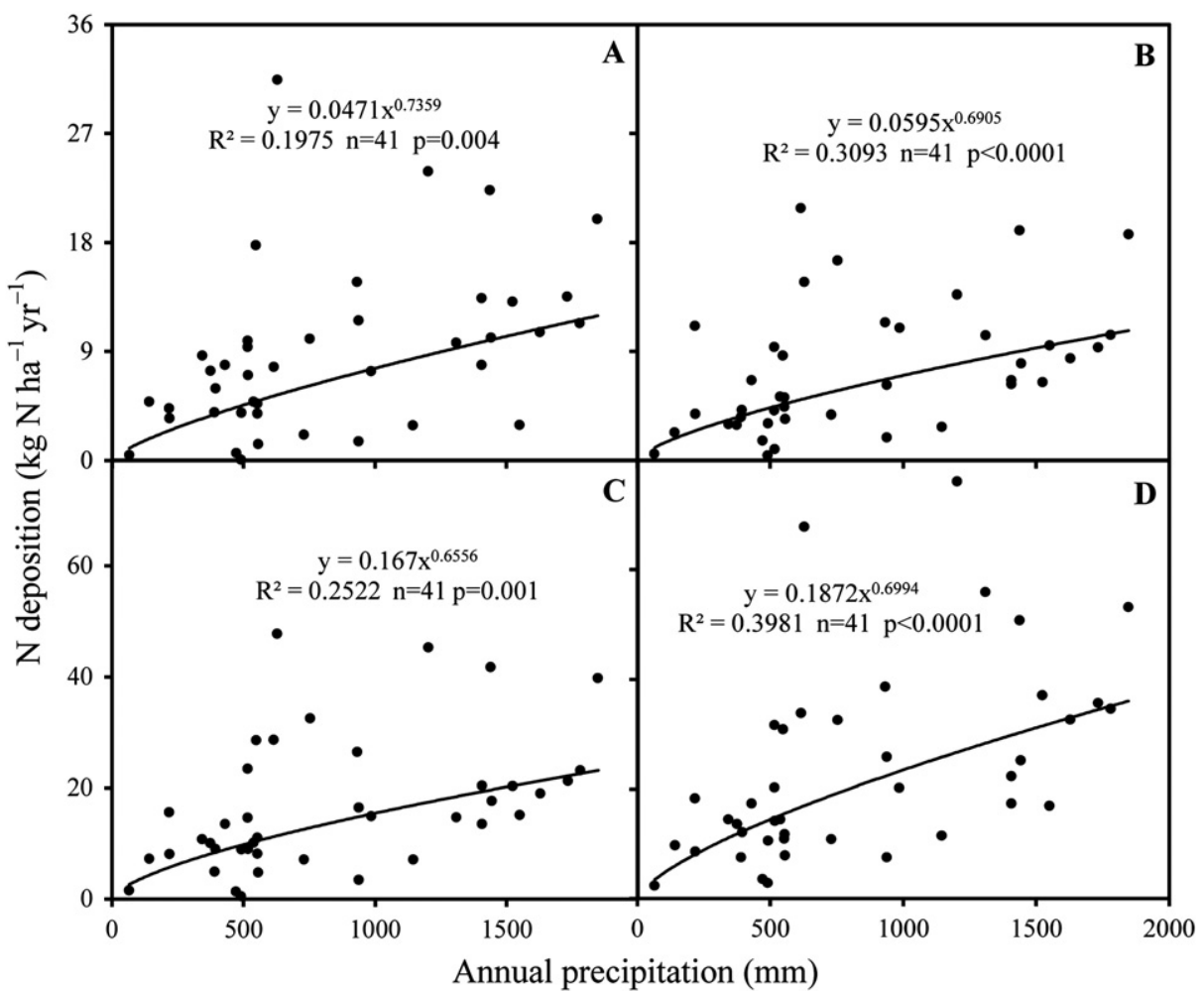

Fig. 5. Effect of annual precipitation on atmospheric wet $\mathrm{N}$ deposition. $\mathrm{A}, \mathrm{NH}_{4}^{+}-\mathrm{N}$ deposition; $\mathrm{B}, \mathrm{NO}_{3}^{-}-\mathrm{N}$ deposition; $\mathrm{C}$, total dissolved $\mathrm{N}$ deposition; $\mathrm{D}$, total $\mathrm{N}$ deposition. 


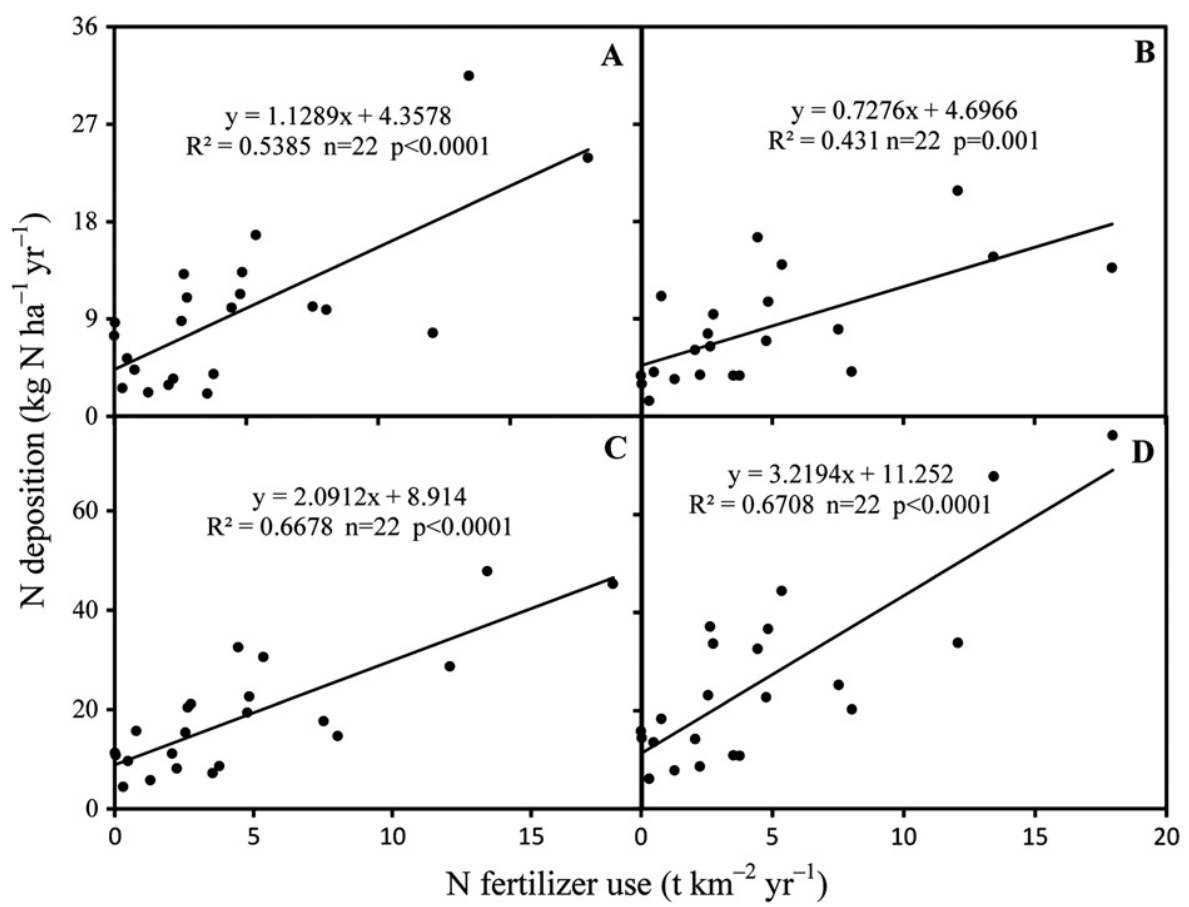

Fig. 6. Effect of $\mathrm{N}$ fertilizer use on atmospheric wet $\mathrm{N}$ deposition. $\mathrm{A}, \mathrm{NH}_{4}^{+}-\mathrm{N}$ deposition; $\mathrm{B}, \mathrm{NO}_{3}^{-}-\mathrm{N}$ deposition; $\mathrm{C}$, total dissolved $\mathrm{N}$ deposition; $\mathrm{D}$, total $\mathrm{N}$ deposition.

demonstrated that atmospheric $\mathrm{N}$ deposition was $13.2 \mathrm{~kg} \mathrm{~N} \mathrm{ha}^{-1} \mathrm{yr}^{-1}$

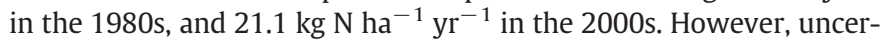
tainties in the estimate of atmospheric wet $\mathrm{N}$ deposition in China still exist because of the different data sources, methods, and study periods involved.

The deposition of DON estimated in this study was approximately $0.52 \mathrm{~kg} \mathrm{~N} \mathrm{ha}^{-1} \mathrm{yr}^{-1}$, which is lower than those of previous studies (Jiang et al., 2013; Zhang et al., 2012b). Some studies have reported that DON accounted for $15-35 \%$ of TDN at single sites or regional scales (Fang et al., 2008; Li et al., 2012; Zhang et al., 2012b). In this study, the wet deposition of DON ranged from 0 to $7.71 \mathrm{~kg} \mathrm{~N} \mathrm{ha}^{-1} \mathrm{yr}^{-1}$, which implied significant DON variation among different observation sites. Further studies therefore are required to clarify the wet deposition of DON at different scales.

The wet deposition of $\mathrm{NH}_{4}^{+}-\mathrm{N}$ and $\mathrm{NO}_{3}^{-}-\mathrm{N}$ were $7.25 \mathrm{~kg} \mathrm{~N} \mathrm{ha}^{-1} \mathrm{yr}^{-1}$ and $5.93 \mathrm{~kg} \mathrm{~N} \mathrm{ha}^{-1} \mathrm{yr}^{-1}$ in 2013, respectively, and the average ratio of $\mathrm{NH}_{4}^{+} / \mathrm{NO}_{3}^{-}$was 1.22 in China. The ratio of $\mathrm{NH}_{4}^{+} / \mathrm{NO}_{3}^{-}$is widely considered a proxy for the sources of atmospheric reactive $\mathrm{N}$ (Huang et al., 2013; Xie et al., 2008). Agricultural activity is the main source of reactive $\mathrm{N}$ if the ratio is larger than 1 , whereas, industrial activity is the main

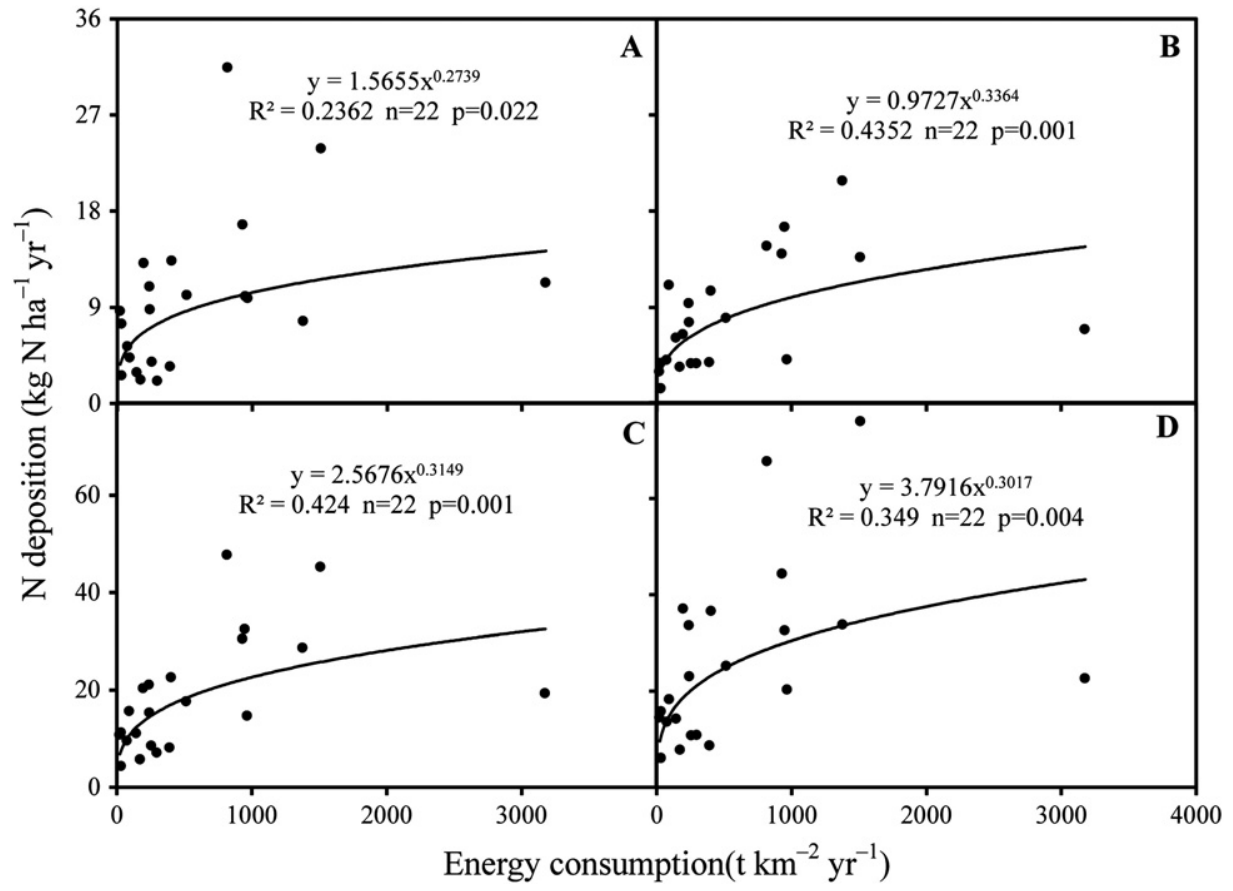

Fig. 7. Effect of energy consumption on atmospheric wet $\mathrm{N}$ deposition. $\mathrm{A}, \mathrm{NH}_{4}^{+}-\mathrm{N}$ deposition; $\mathrm{B}, \mathrm{NO}_{3}^{-}-\mathrm{N}$ deposition; $\mathrm{C}$, total dissolved $\mathrm{N}$ deposition; $\mathrm{D}$, total $\mathrm{N}$ deposition. 
Table 2

Parameters of multiple linear regressions.

\begin{tabular}{|c|c|c|c|c|c|}
\hline $\mathrm{N}_{\text {compositions }}{ }^{\mathrm{a}}$ & $\mathrm{a}$ & $\mathrm{b}$ & $F$ & $R^{2}$ & $p$ \\
\hline $\mathrm{NH}_{4}^{+}-\mathrm{N}$ & 1.126 & 0.005 & 53.98 & 0.828 & $<0.0001$ \\
\hline $\mathrm{NO}_{3}^{-}-\mathrm{N}$ & 0.79 & 0.004 & 44.84 & 0.799 & $<0.0001$ \\
\hline TDN & 2.157 & 0.009 & 90.15 & 0.890 & $<0.0001$ \\
\hline TN & 3.044 & 0.014 & 114.35 & 0.912 & $<0.0001$ \\
\hline
\end{tabular}

a Multiple linear regressions equation: $D_{N}=\mathrm{a} * F_{N}+\mathrm{b} * P$, where $D_{N}$ represents the $\mathrm{N}$ deposition; $F_{N}$ represents $\mathrm{N}$ fertilizer use; $P$ represents annual precipitation; and $\mathrm{a}, \mathrm{b}$ are regression coefficients.

source if the ratio is lower than 1 . The ratio of $\mathrm{NH}_{4}^{+} / \mathrm{NO}_{3}^{-}$in China was 1.22 , which indicates that, as a developing country with a large population, both agricultural and industrial activities collectively influence the deposition of atmospheric $\mathrm{N}$. Meanwhile, the deposition of $\mathrm{NH}_{4}^{+}-\mathrm{N}$ and $\mathrm{NO}_{3}^{-}-\mathrm{N}$ for China was higher than that for America or Europe (Table 3), in agreement with previous studies (Cape et al., 2012; Enzai et al., 2014; Galloway et al., 2004; Lü and Tian, 2007).

The deposition of TN for China in 2013 was approximately $18.02 \mathrm{~kg} \mathrm{~N} \mathrm{ha}^{-1} \mathrm{yr}^{-1}$, and TPN was approximately $4.33 \mathrm{~kg} \mathrm{~N} \mathrm{ha}^{-1} \mathrm{yr}^{-1}$, , contributing $24 \%$ of TN. Previous studies have focused mainly on dissolved wet deposition $\mathrm{N}$, including TDN or DIN $\left(\mathrm{NH}_{4}^{+}-\mathrm{N}\right.$ and $\left.\mathrm{NO}_{3}^{-}-\mathrm{N}\right)$ (Cui et al., 2014; Shen et al., 2013; Zhang et al., 2006; Jia et al., 2014), ignoring TPN. Furthermore, the deposition of TPN via rainfall has not been considered into dry deposition. Therefore, previous studies have underestimated the flux of atmospheric wet $\mathrm{N}$ deposition owing to ignoring TPN. Qi et al. (2013) estimated atmospheric N deposition as $18.38 \mathrm{~kg} \mathrm{~N} \mathrm{ha}^{-1} \mathrm{yr}^{-1}$ in the Yellow Sea, with $39 \%$ of $\mathrm{N}$ dry deposition. Holland et al. (2005) reported that the contribution of dry deposition was $37 \%$ in America and $41 \%$ in Europe (Table 3). If we assume that the contribution of dry deposition was also approximately $40 \%$ in China, and then the total $\mathrm{N}$ deposition in China would be $30.03 \mathrm{~kg} \mathrm{~N} \mathrm{ha}^{-1} \mathrm{yr}^{-1}$. To improve this estimate, more work is required to investigate the concentration of particulates in different regions in order to estimate atmospheric deposition accurately (Wolf and Hidy, 1997).

The influence of local emission sources on atmospheric $\mathrm{N}$ deposition has significant geographic limitations. Cities emit large amounts of pollutants and atmospheric transportation provides a means for pollutants to migrate and transform (Aneja et al., 2001; Behera et al., 2013; Holland et al., 2005). Most observational sites in this study were located in natural ecosystems, and therefore provided a good opportunity to explore the sources and the diffusive distances of atmospheric $\mathrm{N}$ deposition, using the relationship between $\mathrm{N}$ deposition and the distance from the observation site to the provincial capital. The observed atmospheric $\mathrm{N}$ deposition was negatively correlated with the distance from the provincial capital (Fig. 4). Bettez et al. (2013) suggested that more work is required to estimate transport distances for the gaseous $\mathrm{N}$ emissions, which are especially important to estimate ecosystem $\mathrm{N}$ budgets or to control $\mathrm{N}$ loading in $\mathrm{N}$ limited terrestrial ecosystems.

Precipitation, $\mathrm{N}$ fertilizer use, and energy consumption were significantly correlated with atmospheric wet $\mathrm{N}$ deposition (Figs. 5, 6, and 7). Precipitation is an important driver of the spatial patterns of wet $\mathrm{N}$ deposition across large areas. Walaszek et al. (2013) also proposed that the national $\mathrm{N}$ deposition budget was strongly correlated with precipitation, while the variability of annual precipitation did not change the general spatial patterns of wet deposition. Using models and stable isotope methods, many studies have demonstrated that anthropogenic emissions are the main source of atmospheric $\mathrm{N}$ deposition (Dentener et al., 2006; Jia and Chen, 2010; Zhang et al., 2012a). Galloway et al. (2008) suggested that controlling reactive $\mathrm{N}$ emissions from fossil fuel combustion using maximum feasible reduction would result in a decrease of reactive $\mathrm{N}$ creation of 25 to $7 \mathrm{Tg} \mathrm{N} \mathrm{yr}^{-1}$, which could significantly decreased atmospheric $\mathrm{N}$ deposition. $\mathrm{N}$ fertilizers and energy consumption were the two important sources for atmospheric $\mathrm{N}$ deposition, we could therefore control atmospheric N deposition to some extent by reducing energy consumption and the use of $\mathrm{N}$ fertilizers in future.

Precipitation and $\mathrm{N}$ fertilizers collectively explain $80-91 \%$ of the spatial variation in atmospheric $\mathrm{N}$ deposition in China, whereas energy consumption did not significantly explain the variability. Therefore, the final fitted equations did not include the parameter of energy consumption (Table 2), although precipitation, $\mathrm{N}$ fertilizer use, and energy consumption were all significantly correlated with atmospheric wet $\mathrm{N}$ deposition. $\mathrm{N}$ fertilizer use was the main driving factor in analysis of the spatial patterns of the wet $\mathrm{N}$ deposition in China, which could partly explain why the $\mathrm{NH}_{4}^{+} / \mathrm{NO}_{3}^{-}$ratio was higher than 1 in this region.

In summary, atmospheric wet $\mathrm{N}$ deposition in China shows apparent spatial variability, and precipitation, $\mathrm{N}$ fertilizer use, and energy consumption were all significantly correlated with wet $\mathrm{N}$ deposition. Our study demonstrated the composition of wet $\mathrm{N}$ deposition through rainfall events in China, highlighted the importance of TPN in wet $\mathrm{N}$ deposition, and verified the assumption that ignoring the TPN deposition will result in a serious underestimate for wet $\mathrm{N}$ deposition. These findings
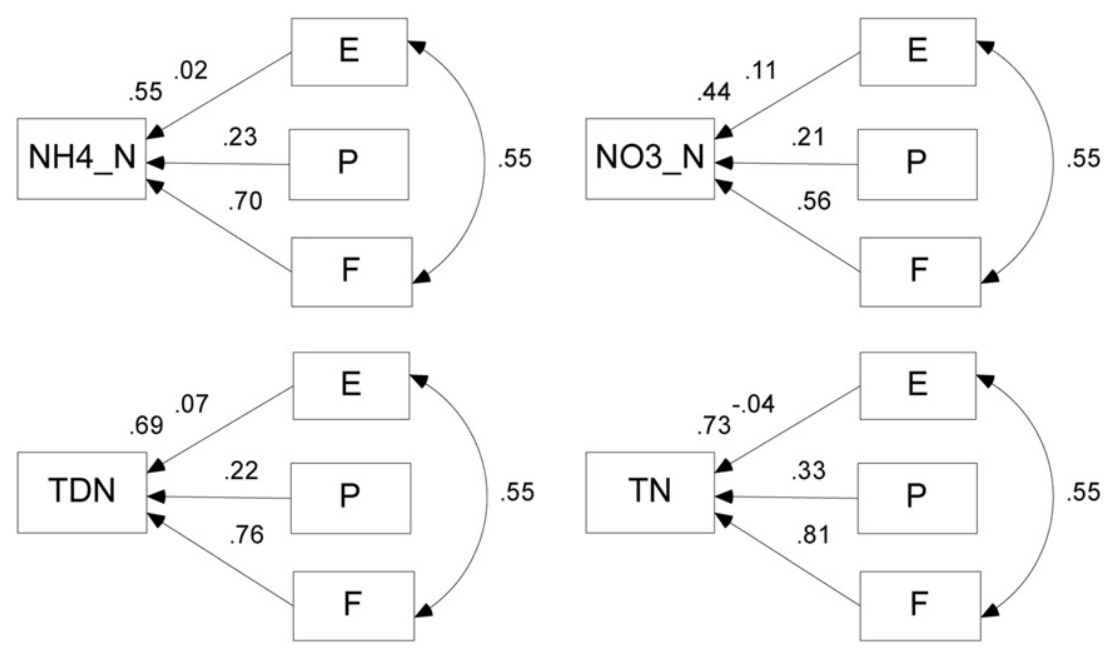

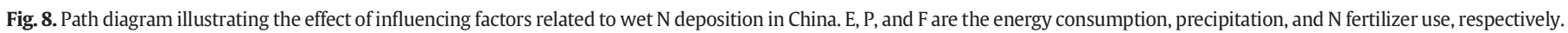
Standardized correlation coefficients are labeled in the figure. 
Table 3

Estimation and relative contributions of wet and dry deposition in different regions.

\begin{tabular}{|c|c|c|c|c|c|c|c|}
\hline \multirow[t]{2}{*}{ Reference } & \multirow[t]{2}{*}{ Area } & \multicolumn{3}{|c|}{ Wet deposition $\left(\mathrm{kg} \mathrm{N} \mathrm{ha}^{-1} \mathrm{yr}^{-1}\right)$} & \multirow[t]{2}{*}{$\mathrm{NH}_{4}^{+} / \mathrm{NO}_{3}^{-}$} & \multirow[t]{2}{*}{ Dry deposition $\left(\mathrm{kg} \mathrm{N} \mathrm{ha}^{-1} \mathrm{yr}^{-1}\right)$} & \multirow[t]{2}{*}{ Dry deposition/total deposition } \\
\hline & & $\mathrm{NH}_{4}^{+}-\mathrm{N}$ & $\mathrm{NO}_{3}^{-}-\mathrm{N}$ & TPN & & & \\
\hline Holland et al. (2005) & America & 1.38 & 1.64 & - & 0.84 & $1.76^{\mathrm{a}}$ & $37 \%$ \\
\hline Holland et al. (2005) & Europe & 4.2 & 2.56 & - & 1.64 & $4.56^{\mathrm{b}}$ & $41 \%$ \\
\hline Du et al. (2014) & America & 2 & 1.5 & - & 1.46 & - & - \\
\hline Cape et al. (2012) & Europe & $0.34-6.52$ & $0.58-4.01$ & - & - & - & - \\
\hline This study & China & 7.25 & 5.93 & 4.33 & 1.22 & - & - \\
\hline
\end{tabular}

a Dry deposition in America includes measured $\mathrm{HNO}_{3}$ (gaseous), particulate $\mathrm{NH}_{4}^{+}$, and particulate $\mathrm{NO}_{3}^{-}$.

b Dry deposition in Europe includes measured $\mathrm{NO}_{2}$ (gaseous), $\mathrm{HNO}_{3}$ (gaseous), particulate $\mathrm{NH}_{4}^{+}$, and particulate $\mathrm{NO}_{3}^{-}$.

provide a useful framework for exploring the ecological effects of atmospheric $\mathrm{N}$ deposition on terrestrial ecosystems.

\section{Acknowledgments}

We are grateful to the ecological stations and all monitors from the Chinese Ecosystem Research Network (CERN) for sample collecting. Funding for this work came from the Natural Science Foundation of China (31290221, 31470506), the "Strategic Priority Research Program - Climate Change: Carbon Budget and Related Issues" of the Chinese Academy of Sciences (XDA05050601), and the Program for Distinguished Talents in Institute of Geographic Sciences and Natural Resources Research (2103RC102).

\section{Appendix A. Supplementary data}

Supplementary data to this article can be found online at http://dx. doi.org/10.1016/j.scitotenv.2014.12.038.

\section{References}

Aber, J.D., Nadelhoffer, K.J., Steudler, P., Melillo, J.M., 1989. Nitrogen saturation in northern forest ecosystems. Bioscience 39, 378-386.

Aneja, V.P., Roelle, P.A., Murray, G.C., Southerland, J., Erisman, J.W., Fowler, D., et al., 2001. Atmospheric nitrogen compounds II: emissions, transport, transformation, deposition and assessment. Atmos. Environ. 35, 1903-1911.

Behera, S.N., Sharma, M., Aneja, V.P., Balasubramanian, R., 2013. Ammonia in the atmosphere: a review on emission sources, atmospheric chemistry and deposition on terrestrial bodies. Environ. Sci. Pollut. Res. 20, 8092-8131.

Bettez, N.D., Marino, R., Howarth, R.W., Davidson, E.A., 2013. Roads as nitrogen deposition hot spots. Biogeochemistry 114, 149-163.

Bobbink, R., Hicks, K., Galloway, J., Spranger, T., Alkemade, R., Ashmore, M., et al., 2010. Global assessment of nitrogen deposition effects on terrestrial plant diversity: a synthesis. Ecol. Appl. 20, 30-59.

Bowman, W.D., Cleveland, C.C., Halada, L., Hresko, J., Baron, J.S., 2008. Negative impact of nitrogen deposition on soil buffering capacity. Nat. Geosci. 1, 767-770.

Cape, J.N., Tang, Y.S., Gonzalez-Benitez, J.M., Mitosinkova, M., Makkonen, U., Jocher, M., et al., 2012. Organic nitrogen in precipitation across Europe. Biogeosciences 9, 4401-4409.

Chen, X.Y., Mulder, J., 2007. Atmospheric deposition of nitrogen at five subtropical forested sites in South China. Sci. Total Environ. 378, 317-330.

Chen, N., Hong, H., Huang, Q., Wu, J., 2011. Atmospheric nitrogen deposition and its longterm dynamics in a southeast China coastal area. J. Environ. Manag. 92, 1663-1667.

Cui, J., Zhou, J., Peng, Y., He, Y.Q., Yang, H., Mao, J.D., 2014. Atmospheric wet deposition of nitrogen and sulfur to a typical red soil agroecosystem in Southeast China during the ten-year monsoon seasons (2003-2012). Atmos. Environ. 82, 121-129.

Dentener, F., Drevet, J., Lamarque, J., Bey, I., Eickhout, B., Fiore, A., et al., 2006. Nitrogen and sulfur deposition on regional and global scales: a multimodel evaluation. Global Biogeochem. Cycles 20, GB4003.

Du, E.Z., de Vries, W., Galloway, J.N., Hu, X.Y., Fang, J.Y., 2014. Changes in wet nitrogen deposition in the United States between 1985 and 2012. Environ. Res. Lett. 9 http://dx. doi.org/10.1088/1748-9326/9/9/095004.

Enzai, D., Wim de, V., James, N.G., Xueyang, H., Jingyun, F., 2014. Changes in wet nitrogen deposition in the United States between 1985 and 2012. Environ. Res. Lett. 9, 095004.

Fang, Y.T., Gundersen, P., Mo, J.M., Zhu, W.X., 2008. Input and output of dissolved organic and inorganic nitrogen in subtropical forests of South China under high air pollution. Biogeosciences 5, 339-352.

Fleischer, K., Rebel, K., Molen, M., Erisman, J., Wassen, M., Loon, E., et al., 2013. The contribution of nitrogen deposition to the photosynthetic capacity of forests. Global Biogeochem. Cycles 27, 1-13.

Fu, B.J., Li, S.G., Yu, X.B., Yang, P., Yu, G.R., Feng, R.G., et al., 2010. Chinese ecosystem research network: progress and perspectives. Ecol. Complex. 7, 225-233.
Galloway, J.N., Dentener, F.J., Capone, D.G., Boyer, E.W., Howarth, R.W., Seitzinger, S.P., et al., 2004. Nitrogen cycles: past, present, and future. Biogeochemistry 70, 153-226.

Galloway, J.N., Townsend, A.R., Erisman, J.W., Bekunda, M., Cai, Z.C., Freney, J.R., et al., 2008. Transformation of the nitrogen cycle: recent trends, questions, and potential solutions. Science 320, 889-892.

Holland, E.A., Braswell, B.H., Sulzman, J., Lamarque, J.F., 2005. Nitrogen deposition onto the United States and Western Europe: synthesis of observations and models. Ecol. Appl. 15, 38-57.

Huang, Y.L., Lu, X.X., Chen, K., 2013. Wet atmospheric deposition of nitrogen: 20 years measurement in Shenzhen City, China. Environ. Monit. Assess. 185, 113-122.

Jia, G., Chen, F., 2010. Monthly variations in nitrogen isotopes of ammonium and nitrate in wet deposition at Guangzhou, South China. Atmos. Environ. 44, 2309-2315.

Jia, Y., Yu, G., He, N., Zhan, X., Fang, H., Sheng, W., et al., 2014. Spatial and decadal variations in inorganic nitrogen wet deposition in China induced by human activity. Sci. Rep. 4.

Jiang, C.M., Yu, W.T., Ma, Q., Xu, Y.G., Zou, H., Zhang, S.C., et al., 2013. Atmospheric organic nitrogen deposition: analysis of nationwide data and a case study in Northeast China. Environ. Pollut. 182, 430-436.

Kopacek, J., Cosby, B.J., Evans, C.D., Hruska, J., Moldan, F., Oulehle, F., et al., 2013. Nitrogen, organic carbon and sulphur cycling in terrestrial ecosystems: linking nitrogen saturation to carbon limitation of soil microbial processes. Biogeochemistry 115, 33-51.

Li, J., Fang, Y.T., Yoh, M., Wang, X.M., Wu, Z.Y., Kuang, Y.W., et al., 2012. Organic nitrogen deposition in precipitation in metropolitan Guangzhou City of southern China. Atmos. Res. 113, 57-67.

Liu, X.J., Duan, L., Mo, J.M., Du, E.Z., Shen, J.L., Lu, X.K., et al., 2011. Nitrogen deposition and its ecological impact in China: an overview. Environ. Pollut. 159, 2251-2264.

Liu, X.J., Zhang, Y., Han, W.X., Tang, A.H., Shen, J.L., Cui, Z.L., et al., 2013. Enhanced nitrogen deposition over China. Nature 494, 459-462.

Lü, C.Q., Tian, H.Q., 2007. Spatial and temporal patterns of nitrogen deposition in China: synthesis of observational data. J. Geophys. Res. 112, D22.

Maljanen, M., Yli-Pirila, P., Hytonen, J., Joutsensaari, J., Martikainen, P.J., 2013. Acidic northern soils as sources of atmospheric nitrous acid (HONO). Soil Biol. Biochem. 67, 94-97.

Neff, J.C., Holland, E.A., Dentener, F.J., McDowell, W.H., Russell, K.M., 2002. The origin, composition and rates of organic nitrogen deposition: a missing piece of the nitrogen cycle? Biogeochemistry 57, 99-136.

Qi, J.H., Shi, J.H., Gao, H.W., Sun, Z., 2013. Atmospheric dry and wet deposition of nitrogen species and its implication for primary productivity in coastal region of the Yellow Sea, China. Atmos. Environ. 81, 600-608.

Reay, D.S., Dentener, F., Smith, P., Grace, J., Feely, R.A., 2008. Global nitrogen deposition and carbon sinks. Nat. Geosci. 1, 430-437.

Shen, J.L., Li, Y., Liu, X.J., Luo, X.S., Tang, H., Zhang, Y.Z., et al., 2013. Atmospheric dry and wet nitrogen deposition on three contrasting land use types of an agricultural catchment in subtropical central China. Atmos. Environ. 67, 415-424.

Sheng, W.P., Yu, G.R., Jiang, C.M., Yan, J.H., Liu, Y.F., Wang, S.L., et al., 2013. Monitoring nitrogen deposition in typical forest ecosystems along a large transect in China. Environ. Monit. Assess. 185, 833-844.

Stevens, C.J., Dise, N.B., Mountford, J.O., Gowing, D.J., 2004. Impact of nitrogen deposition on the species richness of grasslands. Science 303, 1876-1879.

Thomas, R.Q., Canham, C.D., Weathers, K.C., Goodale, C.L., 2010. Increased tree carbon storage in response to nitrogen deposition in the US. Nat. Geosci. 3, 13-17.

Ti, C.P., Pan, J.J., Xia, Y.Q., Yan, X.Y., 2012. A nitrogen budget of mainland China with spatial and temporal variation. Biogeochemistry 108, 381-394.

Vitousek, P.M., Aber, J.D., Howarth, R.W., Likens, G.E., Matson, P.A., Schindler, D.W., et al., 1997. Human alteration of the global nitrogen cycle: sources and consequences. Ecol. Appl. 7, 737-750.

Walaszek, K., Kryza, M., Dore, A.J., 2013. The impact of precipitation on wet deposition of sulphur and nitrogen compounds. Ecol. Chem. Eng. S 20, 733-745.

Wolf, M.E., Hidy, G.M., 1997. Aerosols and climate: anthropogenic emissions and trends for 50 years. J. Geophys. Res. 102, 11113-11121.

Xie, Y., Xiong, Z., Xing, G., Yan, X., Shi, S., Sun, G., et al., 2008. Source of nitrogen in wet deposition to a rice agroecosystem at Tai lake region. Atmos. Environ. 42, 5182-5192.

Yearbook CS, 2001-2010aa. Department of Energy Statistics, National Bureau of statistics of China. China Energy Statistical Yearbook. China Statistical Press (Available at http://data.stats.gov.cn/workspace/index? $\mathrm{m}=$ fsnd (in Chinese)).

Yearbook CS, 2001-2010bb. National Bureau of statistics of China. China Statistical Yearbook. China Statistical Press (Available at http://data.stats.gov.cn/workspace/index? $\mathrm{m}=\mathrm{fs}$ (in Chinese)). 
Yu, W.T., Jiang, C.M., Ma, Q., Xu, Y.G., Zou, H., Zhang, S.C., 2011. Observation of the nitrogen deposition in the lower Liaohe River Plain, Northeast China and assessing its ecological risk. Atmos. Res. 101, 460-468.

Zhan, X., Yu, G., He, N., Fang, H., Jia, B., Zhou, M., et al., 2014. Nitrogen deposition and its spatial pattern in main forest ecosystems along north-south transect of eastern China. Chin. Geogr. Sci. 24, 137-146.

Zhang, Y., Liu, X., Zhang, F., Ju, X., Zou, G., Hu, K., 2006. Spatial and temporal variation of atmospheric nitrogen deposition in the North China Plain. Acta Ecol. Sin. 26, 1633-1638.
Zhang, L., Jacob, D.J., Knipping, E.M., Kumar, N., Munger, J.W., Carouge, C.C., et al., 2012a. Nitrogen deposition to the United States: distribution, sources, and processes. Atmos. Chem. Phys. 12, 4539-4554.

Zhang, Y., Song, L., Liu, X.J., Li, W.Q., Lü, S.H., Zheng, L.X., et al., 2012b. Atmospheric organic nitrogen deposition in China. Atmos. Environ. 46, 195-204. 